\title{
Conservation and development
}

\author{
Protecting Madagascar's unique biodiversity can improve the life of many in the country.
}

\begin{abstract}
n December 2018, with nearly $56 \%$ of the vote, former president Andry Rajoelina won the run-off elections to once again become the president of Madagascar ${ }^{1}$. He had launched his electoral campaign under the slogan 'Emergence de Madagascar' at the beginning of $2018^{2}$, focusing on the economy and the fight to end corruption and poverty. He took office on 18th January 2019.

Promises of improved economic conditions were surely welcomed by the Malagasy population. Although positive,
\end{abstract} Madagascar's economic growth is far from being inclusive. According to the 2018 economic update from the World Bank Group $^{3}$, the Malagasy economy grew over the last 4 years and is projected to continue to grow throughout 2019. Despite such good performance at the aggregate level, key sectors of the economy continue to struggle. In particular, the agricultural sector that engages about $80 \%$ of the population lags behind, with local rice production unable to keep up with the demand of a growing population. While urban households have access to cheaper rice imported from abroad, rural households are left behind at times of reduced local supply.

General conditions are very poor in the country, with a high level of stunting in children under the age of 5 , and a large number of out-of-school children. Madagascar also has an extremely low rate of access to electricity. According to the Human Development Index as measured by the United Nations Development Programme, in 2018 the country fell three places in the world ranking, from 158 to 161 (ref. ${ }^{4}$ ). Overall, despite economic growth, the current living conditions of most of the population cannot ensure an adequate level of well-being.

But Madagascar is an incredibly rich biodiversity hotspot. The World Database of Key Biodiversity Areas (KBAs) defines KBAs as 'sites contributing significantly to the global persistence of biodiversity' and lists 247 of them in Madagascar ${ }^{5}$. According to data from the Convention on Biological Diversity, Madagascar is a mega-diverse country with a high concentration of endemic species. For example, there are 12,000 species of vascular plants (of which $96 \%$ are endemic), 278 species of amphibians (100\% endemic), 104 species and subspecies of lemurs ( $100 \%$ endemic), to name just a few ${ }^{6}$. Of course, it's our responsibility to

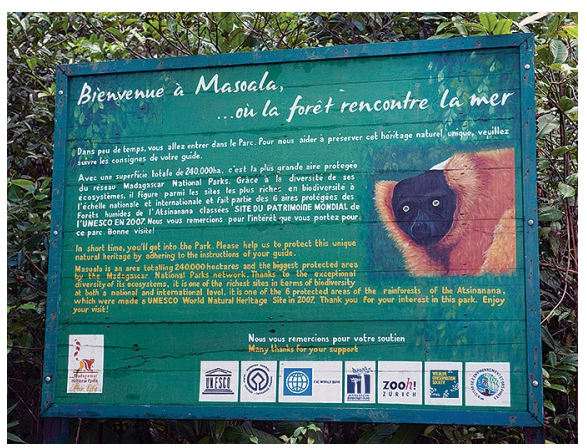

Credit: Papilio / Alamy Stock Photo

preserve such a unique environment researchers and leaders of non-governmental organizations have repeatedly called for more and better public and private support for conservation efforts in Madagascar. Unfortunately, as of today, Malagasy biodiversity remains under severe threat.

In a Comment, Julia Jones and colleagues posit that biodiversity conservation can and should be an integral part of effective development strategies in a country like Madagascar, where most of the population depends on natural resources and can derive income from managing them sustainably. In other words, they hint that conservation efforts should not be considered an additional burden on the limited financial resources available to stimulate the economy. Investing in maintenance and enhancement of biodiversity can generate income and livelihoods for local communities and the country as a whole.

Jones and colleagues discuss how increasing income from the tourism sector, an issue mentioned in Rajoelina's campaign, hinges on biodiversity conservation. Most of the tourists travelling to Madagascar, as in the case of other countries with unique biodiversity sites, are attracted by the opportunity to visit protected areas (PAs). But in a country where the rule of law is in decline, PAs are exposed to mismanagement due to corruption and visits to the sites might decrease due to the perception of insecurity.

The authors propose five ways to improve the state of Madagascar's biodiversity, and hope to reach out to President Rajoelina with this plan of action to stimulate debate about the future of conservation and development in Madagascar.
One of the proposed strategies is to increase investment in the country's PAs. The existing Madagascar Biodiversity Fund has invested in PAs but the income generated by such investment is vastly insufficient to cover the management costs of all PAs. Reforms to create the right institutional and economic environment in combination with investments in infrastructure for tourism are needed. And it is crucial to adequately include the needs of the local communities in any intervention.

Protected areas are increasingly being scrutinized - they require initial and ongoing investments, and it is not always clear the extent to which they effectively avoid biodiversity loss. Jones and colleagues acknowledge such concerns as PAs have not stopped deforestation in Madagascar, but feel that, if better resourced, they remain a useful tool. The issues with underperforming PAs are not limited to insufficient resources. Managers might lack specific knowledge on trends in the wealth of species, a gap that calls for critical knowledge transfer from researchers to practitioners ${ }^{7}$.

Investing in PAs is part of the solution. Tackling the declining rule of law, particularly in the case of environmental crime, and strengthening the tenure rights of local people to better manage natural resources will also be part of the solution. Ultimately, Madagascar needs political will to change the current trajectory of biodiversity loss and marginalization of local communities. President Rajoelina has the opportunity to act wisely and embrace change in the interest of the country. We are all watching him.

Published online: 13 May 2019

https://doi.org/10.1038/s41893-019-0298-y

References

1. Madagascar ex-leader Andry Rajoelina wins presidential runoff vote. BBC News https://go.nature.com/2GE0KWQ (27 December 2018)

2. Andry Rajoelina plans political comeback in Madagascar. $D W$ https://go.nature.com/2WcOzaf (7 August 2018).

3. Madagascar Economic Update: Fostering Financial Inclusion https://go.nature.com/2GKCLqw (World Bank Group, June 2018).

4. The World Bank in Madagascar https://go.nature.com/2GFMaOv (The World Bank, accessed 24 April 2019).

5. World Database of Key Biodiversity Areas; https://go.nature. com/2XDTQb8

6. Madagascar-Country Profile https://go.nature.com/2ZxCbnn (Convention on Biological Diversity, accessed 24 April 2019).

7. Pyhälä, A., Eklund, J., McBride, M. F., Rakotoarijaona, M. A. \& Cabeza, M. Conserv. Sci. Pract. 1, e6 (2019). 